\title{
Post Disaster Housing Reconstruction after 2014 Gaza Strip's Conflict: Influencing Factors
}

\author{
Abeer Said Alfaseeh, Bassam A Tayeh* and Nabil El Sawalhi \\ Department of Civil Engineering, The Islamic University of Gaza, Palestine
}

Submission: May 20, 2019; Published: July 02, 2019

*Corresponding author: Bassam A Tayeh, Department of Civil Engineering, Islamic University of Gaza, Gaza, Palestine

\begin{abstract}
Housing reconstruction projects are complex in nature because of the many stages and also the many stakeholders they have. The objective of this study is to investigate the main factors influencing the reconstruction process of the housing sector following the Gaza Strip conflict in 2014. A literature review was conducted and factors affecting housing reconstruction were extracted. A questionnaire was developed by identifying the most important and reliable factors that achieve the research objective. Seven sets of factors were identified to facilitate the analysis of 64 factors with the help of a pre-test for the questionnaire with the help of the Ministry of Public Works and Housing in the Gaza Strip. 98 questionnaires were distributed, but only 90 questionnaires were collected. SPSS was used to analyze factors and relative important index (RII) was the tool that ranked the factors. The main influencing group was "Factors Related to Institutions Involved in Reconstruction Projects", but at the bottom of the ranking was the "Governmental Factors".

The study concluded that the factors associated with institutions such as the international organization are the main key to support housing reconstruction in the Gaza Strip, which is clear in the case of the Gaza Strip as a developing country. The increasing efficiency of reconstruction will be illustrated by highlighting factors related to institutional participation, such as differences in experience among participants, especially engineers, sustainable machinery support, manpower with different experience, understanding of legislation and policies by engineers, each participant should have a good practice to manage any issue of reconstruction and a prepared a plan to mitigate the risk of post-disaster in the future. And other important factors for the other groups were determined for more efficient work when reconstruct such as having efficiency of the management of the government, emergency plans by the parties who concern of reconstructing the Gaza Strip, fitting between donors conditions and beneficiaries' needs, prepared program by the government to deal with these projects, effective role of municipality, effective disaster assessment to figure out the appropriate amount of funds, efficiency in defining the responsibilities for every participant in these projects and considering the justice when giving the priority to reconstruct to the beneficiaries.
\end{abstract}

Keywords: Post disaster; Gaza Strip; Housing reconstruction; Challenged factors; Influencing factors

\section{Introduction}

Post disaster housing reconstruction is taking a good place in the world's interest due to the repeated natural disasters such as earthquakes, tsunamis and in other cases it is man-made causes, such as the conflicts, which increased the interest of having reconstruction after disasters. The Gaza Strip is one of those areas which had a man-made disaster. 3 conflicts in 10 years and the biggest one was on the third of July 2014, so the necessity of having a reconstruction appeared to be urgent. But Enshassi, et al. [1] said that financial issues are the first key to control the housing reconstruction process in the Gaza Strip. Anyway, the barriers of the post disaster reconstruction are everywhere, but the differences are in the type of challenges. Ismail, et al. [2] showed that community participation, assessment, funding and quality of work are the main challenges of the post disaster reconstruction in many countries around Indonesia. That's why some development plans should be prepared for such disasters insect, some temporary construction should be done after catastrophes to help people to have some settlement [3]. The Gaza Strip is a crowded country full of buildings. According to the Palestinian Central Bureau of Statistics (PCBS, 2017) there were 403,259 housing units and 186,156 Building in the Gaza Strip. And according to General Directorate of Customs Security [4] many of housing reconstruction had been done during the last 5 years. About 800-1100 housing units should be prepared annually in the Gaza Strip to follow the previous situations before the conflict occurring, due to Ministry of Public Works and Housing MPWH [5]. The conflict's results in 2014 were a catastrophe. Table 1 shows the volume of destruction in the Gaza Strip after the conflict [6]. The 100,000 people had become homeless.

Previous numbers show how important the reconstruction is. But in the Gaza Strip the reconstruction process is very slow and full of issues such as being behind the schedule or over the budget and in many cases, reconstructions could not be started or cannot be finished. This research is going to figure out the main factors 


\section{Civil Engineering Research Journal}

that affect the reconstruction process for the housing sector in the Gaza Strip. There is an urgent need to know the factors affecting housing reconstruction in the Gaza Strip to make some suggestion for those departments who concern in these projects.

Table 1: Amount of houses and mosques destructive in the conflict of 2014 Euro-MED [16].

\begin{tabular}{|c|c|c|c|}
\hline Item & $\begin{array}{c}\text { Total } \\
\text { Number }\end{array}$ & $\begin{array}{c}\text { Partial } \\
\text { Destruction }\end{array}$ & $\begin{array}{c}\text { Full } \\
\text { Destruction }\end{array}$ \\
\hline Destructive houses & 31799 & 17132 & 14667 \\
\hline Mosques houses & 171 & 62 & 109 \\
\hline
\end{tabular}

\section{Problem Statement}

A large number of homes were counted after the conflict in the Gaza Strip. But during the years of housing reconstruction in the Gaza Strip, most housing reconstruction projects were behind schedule, over budget, having manpower issues and many issues of project-related assets, and that led to lose the trust of the donors in addition to the beneficiaries.

\section{Research Objectives}

i. Identify the main influencing factors that affect housing reconstruction after disasters.

ii. Rank the main influencing factors that affect housing reconstruction after disasters.

\section{Research significant}

This research aims to identify the factors affecting the reconstruction of housing in the Gaza Strip and then find out the most important factors in terms of impact on this type of projects. In this way, it is possible to identify the real reasons that led to increased time in the implementation of many projects in advance as well as reasons for increased budget and why there are many obstacles to the implementation of the reconstruction of efficient housing projects. In this research, it made efforts to facilitate responsibility for housing reconstruction projects in the Gaza Strip, whether donors, the project implementers or beneficiaries of the project. This can reduce conflict between parties as well as ease of planning and ease of implementation by contractors and enhance the trust of donors.

\section{Scope and limitation}

The scope and limitations of the study are as follows:

I. The scope of this research is focused on the reconstruction Process, mainly housing projects.

II. The research population includes every party that has a direct relationship in executions the reconstruction for the housing sector in the Gaza Strip, such as local ministries, local municipalities, UN, UNDP and engineers with experiences in reconstructing the housing sector.

III. The sample size was small due to the less parties who has a relation in reconstructing the housing sector in the Gaza
Strip. The donor party had a direct controlling and monitoring for their project at the most, and that reduce the volume of local involvement in reconstruction the housing sector in the Gaza Strip.

\section{Background of Study}

The post disaster reconstruction is the first priority when disasters end. But the regular process of construction isn't working for housing reconstruction, especially in the great big areas, in such cases; many factors should be adapted. The government should have a prepared program as preparedness for reconstructing after the sudden great disasters Rotimi et al. [7].

An effective post disaster reconstruction depends on cultural, political, environmental, economic and social elements [8]. The post-destruction, reconstruction of the 2015 Gorkha earthquake in Nepal faced factors which were a combination between positive and negative influences, some of the challenges factors were consisted of the absence of local government, weak governance, weak infrastructure, lack of preparedness, knowledge gap and manpower shortage, on the other hand some other factors played a positive role in the reconstruction process such as the good governance, integrated information, addressing technical issues, public participation along with short term and long-term strategies to tackle with technical issues [9].

Post disaster reconstruction directly affected by the location of the destructed area due to its effects on the funding amount, less in the technical manpower and resources [2]. While the community participation has a major role in the process of housing reconstruction after the disaster, it had become necessary to focus on it and collect more information about it when reconstruct [10].

Weakness in climate, social and economic studies, participation differences and weakness of institutions, undefined assessment of need and capacity, not giving the priority to mitigate disasters affects or having the appropriate safety, weak of connection between stakeholders in addition to the unrealistic decision making by using alternatives or using the appropriate chances and planning, weak of the community involvement due to the lack of permissions to use public or social infrastructure or to be involved with house designing are the main factors that affect resettlement of Sri Lanka [11].

Long term reconstruction after disasters is the hardest in comparison with short or midterms reconstruction, long term reconstruction is full with obstacles and challenges, arrangement should be identified well, due to the many phases and many requirements, especially when planning for resettlement to find out those solutions for long term development [12]. Post disaster faces a very weak term at the beginning of the planning for having a recovery or a reconstruction due to the less funding from donors, and local government in those areas, mostly faces a very shortage in resources or financing to get up from the crises [13]. NGOs can fortunate small projects of reconstructions after disasters, and for 


\section{Civil Engineering Research Journal}

many classified factors, projects with high volume requirements for having appropriate reconstruction projects need more funds from donors [14].

The controlling and the monitoring of the government are the key role, so the funds can reach their beneficiaries as well as it'd supposed to, otherwise the real amount of funding won't reach the beneficiaries, reconstruction won't be able to be completed and the justice will just disappear due to those who have the ability to steal those funds which came from donors or other resources [15]. Focusing on decreasing the repeated issues after a post disaster reconstruction is a main idea. Artiningsih et al. [16] showed that making a formal note as a policy and as a feedback to the government to face future disasters is a methodology for a better post disaster controlling.

Damages of the disasters need to be managed, but different phases should be applied with different emphasis [17]. In addition, post disaster reconstruction has their criteria in implication. But the same stages are exists: Response, Relief, Recovery and reconstruction and then considering the mitigation with preparedness [18]. Reconstructing in general isn't that easy or could go smoothly. Reconstruction goes through complexity and conflicts due to the requirements of the beneficiaries in sometimes [19]. Post disaster reconstruction is a hard project with high amounts of needs [17]. Due to its huge amount of requirements of the activities, that's supposed to start right after disasters [18]. Donors are one of the most important factors that affect the post-disasters reconstruction [1]. Many factors and characteristics or aspects affect the process of housing reconstructing. Construction of houses has its own properties and its own phases. Around the world, disaster's impacts can be easily shown by the great amount of damages every year [20]. The housing reconstruction is needed whenever there are crises or disasters at the residential buildings, reconstruction should be managed by preparing all its requirements: funds, schedules and also every phase that a normal construction needs. One of these factors is choosing a reconstruction type, for helping the beneficiary's owner or donor driven. Tow type of funds exists, for example owner driven role in the reconstruction process affect the reconstruction more positive than the other type of donors, which is the donors driven, due to the unsuitability of the donors help. Both driven owner and donors have their own benefits and success. However, in a different way, owner driven is specialized in reconstructing by the beneficiaries themselves. The donor's driven is specialized in reconstructing by international agencies or by government [21]. More factors affect the housing reconstruction after disasters which can support or obstacle the process of housing reconstruction.

Reconstruction process presents two categories which are housed reconstruction and infrastructure reconstruction [21]. And reconstruction process has a duration of two years and in some cases, it approximated four years, depending on the country's resources [23]. Other studies established that evaluating the period of reconstruction after a disaster depends on many factors.
It's a little bit complicated to have a direct number of years to finish reconstructing, in some cases there is a need to finish as fast as possible to resettle the beneficiaries [24]. Post disaster reconstruction needs stakeholders at the beginning. Stakeholders who are going to join the reconstruction process in particular, need to be in a higher degree of responsibility and have a major effort, in addition to understand the legislation and policies, improving the transportation, marketing and depending on sustainability mechanism whenever planning starts [25].

Delay, work quality, community participation, funded reconstruction being weak, resourcing, preliminary assessment, lack of coordination, corruption and build back safer, land issues, policies, overruns of cost and a shortage of technical staff are the challenge factors of the post disaster reconstruction from INGOs perspective [26]. Reconstruction stage with permanent houses can be presented in a stage called the post disaster reconstruction [23]. The 3 M's are common factors which can be considered as restricting factors in the reconstruction process after disasters. The 3 M's are manpower, material and machine. Any shortage or weakness of the 3 M's will affect the reconstruction process after disaster very badly [27].

Evaluating the requirements of the reconstruction leads to an efficient reconstruction [28]. For an effective post disaster reconstruction, organizations of the country which have a direct relationship with the reconstruction should have a clear set of responsibilities and should have a clear relation with the government [28]. Studying the future and predict what can or can't be expected when starting reconstructing, focusing on the development ideas, having the appropriate information and knowledge, using modern technology of reconstruction and surveying, and better communication and coordination between participants of the post disaster reconstruction projects is a key to better housing reconstruction [14].

\section{Challenges factors affect the period of housing recon- struction}

Hosing reconstruction is a major part of the reconstruction process, which got affected by many factors as well as any part of the reconstruction. Some of the main issues of post disaster reconstruction are the long period of reconstruction in comparison with the logical period of reconstruction. Not finding a suitable land to be built and also the constraints that affect the construction industry are critical issues [21]. Kitamato et al. [29] explained how high amount of care it need when the area Citadel of Bam, Iran was constructed, due to its importance as a heritage area, 8 years is a long time, but it's worth it. Post disaster housing reconstruction has a critical pre-reconstruction stage due to its influences by effective communication, transparency and accountability, government role and support, community view, facilitator capacity and community's shares [30]. Questions such as who make decisions, with whom and what are the influencing resulted from these decisions are the key to good Plano, which can reduce the delay matter) [31]. Tafti \& Tomlinson [32] suggested consid- 


\section{Civil Engineering Research Journal}

ering the development beside the humanitarian concerns in post disaster reconstruction, in addition to submitting the justice distributions of a housing recovery.

\section{Factors affect post disaster housing management}

Tacking in account the vulnerability and adaptive capacity are the main factors to have a good result in managing the development when rebuilding the houses in Sri Lanka after the Tsunami of 2004 [33]. A conclusion of researches established that many factors affects the success of project management when reconstruct after disasters, such as the delay, resourcing, poorly funded reconstruction, preliminary assessment, lack of coordination, corruption and Build back better/safer, policies, quality of works, land issues, cost overruns, a shortage of technical staff and community participation [26]. Reconstruction after disasters is a very complex phase needs a management in high quality to reach a high successful phase [26]. The built environment is a critical zone in defining the management of post disaster housing reconstruction due to its complexity that increases the challenges of the process [34]. Managing a post disaster project needs different participants who have different experience and knowledge, an unplanned group of the project can become as a barrier to an efficient project [35].

Planning for Post disaster recovery as a first will enhance the management phase in all the stages, including the reconstruction stage, for example elements that reduce the risks of disaster should be considered in the design and construction phase [36]. Sri Lanka faced a very poor management due to the large number Table 2: Results of pre-testing the questionnaire. of homeless who need a resettlement after the disaster, in addition, international donors with the local government contract had a gap of making differences between policy and responsibility of the government [37]. Management of post disaster by Maheshiks \& Sangasumana [12] perspective is about having the mechanism of enhancing and the organization and then submitting the laws of admitting sustainability process, in addition of adapting a new method to mitigate the disaster by protecting the area from having erosion. Disaster management will have its efficiency when a good participation can be implied by NGOs and other agencies in the country the National Disaster Management Guidelines [38].

\section{Methodology}

This study is concerned with ranking the most important factors affecting the reconstruction of the housing Sector in the Gaza Strip for an easier future execution by contractors and supervisors (donors and their organizations). Factors had been extracted from the previous literature review and a questionnaire had a pre-testing, the ministry of public works and housing was chosen for this assignment due to its important role in guiding the housing reconstructing in the Gaza Strip. Due to the ministry of public works and housing, these extracted factors weren't that fitting with the reality of the Gaza Strip, in addition, a list of factors cannot follow the goal of this research, but categorizing it into groups of factors should be exist due to the different parties and phases that affect the reconstruction projects. And every group has its own affection on the housing reconstruction projects.

\begin{tabular}{|c|c|c|c|}
\hline I & Factors & Note & Modified Factors \\
\hline A. & \multicolumn{3}{|l|}{ Management factors } \\
\hline 1 & The efficiency of management process in the organization & Selected & \\
\hline 2 & $\begin{array}{l}\text { The management of housing reconstruction after disasters should keep going, with } \\
\text { the existence of the built environment when planing }\end{array}$ & Selected & \\
\hline 3 & $\begin{array}{l}\text { The management of housing reconstruction after disasters should consider the } \\
\text { delay of the process for different reasons when planing }\end{array}$ & Selected & \\
\hline 4 & $\begin{array}{l}\text { Adaptive Capacity of the area of housing reconstruction is a factor for a good } \\
\text { management process }\end{array}$ & Modified & $\begin{array}{l}\text { Adaptive Capacity of the area of housing } \\
\text { reconstruction when planing }\end{array}$ \\
\hline 5 & $\begin{array}{l}\text { Tacking in account the vulnerability of the environment of housing reconstruction } \\
\text { is a factor for a good management process }\end{array}$ & Selected & \\
\hline 6 & Being ready for management process when it needs & Modified & $\begin{array}{l}\text { Plans for housing reconstruction } \\
\text { management should be prepared }\end{array}$ \\
\hline 7 & $\begin{array}{l}\begin{array}{l}\text { Risk mitigation should be as a priority when managing housing reconstruction } \\
\text { projects }\end{array} \\
\end{array}$ & Selected & \\
\hline 8 & Efficiency of the assessment of the requirement for post disaster reconstruction & Selected & \\
\hline 9 & The existence of the material of the reconstruction & Selected & \\
\hline 10 & The good Corporation between organizations & Added & \\
\hline 11 & The good Cooperation between the basic resources of the reconstruction & Added & \\
\hline 12 & Emergency plans to support the management of the reconstruction & Modified & \\
\hline 13 & The existence of special management mechanism for such a project & Modified & $\begin{array}{l}\text { Using the regular mechanism in such a } \\
\text { project }\end{array}$ \\
\hline 14 & Efficiency of the management of the government & Selected & \\
\hline 15 & Differences in politics of the reconstruction between different organizations & Added & \\
\hline
\end{tabular}




\section{Civil Engineering Research Journal}

\begin{tabular}{|c|c|c|c|}
\hline B. & $\begin{array}{c}\begin{array}{c}\text { Factors related to participating in reconstruction projects (international } \\
\text { organization) }\end{array} \\
\end{array}$ & & \\
\hline 1 & Differences in experience between the participants specially the engineers & Selected & \\
\hline 2 & Support sustainable mechanism & Selected & \\
\hline 3 & Differences of the working manpower & Selected & \\
\hline 4 & Being aware of the importance of applying sustainability & Selected & \\
\hline 5 & Understanding the legislation and policies by engineers in the area & Selected & \\
\hline 6 & Effort of working hard by every participant & Selected & \\
\hline 7 & Having a good practice to manage any issue of the reconstruction & Selected & \\
\hline 8 & Planning for post disaster risk reduction in the future & Selected & \\
\hline C. & Stakeholders (beneficiaries) characteristics & & \\
\hline 1 & The volume of those who are in need for these projects (Beneficiaries) & Selected & \\
\hline 2 & Psychological situation & Selected & \\
\hline 3 & Gab of information due to the weakness of incorporation of the beneficiaries & Selected & \\
\hline 4 & Availability of the temporary houses till the reconstruction finishes & Added & \\
\hline 5 & Fitting between owners condition and the needs of the beneficiaries & Added & \\
\hline D. & Technical factors & & \\
\hline 1 & Volume of the destruction of a building & Added & \\
\hline 2 & The amount of landfill resulting from the disaster & Added & \\
\hline 3 & Number of the destructed houses & Selected & \\
\hline 4 & Efficiency and the quality of the work when reconstruct & Selected & \\
\hline 5 & The efficiency of the infrastructure when start the work of reconstructing & Selected & \\
\hline 6 & Efficiency of preliminary assessment & Selected & \\
\hline 7 & Applying safety when reconstruct & Selected & \\
\hline 8 & $\begin{array}{c}\text { Existence of the resources of the reconstruction process such as material, } \\
\text { equipment and manpower }\end{array}$ & Selected & \\
\hline 9 & Integration of information about the process of these projects & Selected & \\
\hline 10 & The requirements of the donors don't fit with the local environment & Added & \\
\hline 11 & Existence of the quality and quantity of materials & Added & \\
\hline 12 & Electricity availability & Selected & \\
\hline 13 & Transparency & Deleted & \\
\hline E. & Government factors & & \\
\hline 1 & Effector role of municipality & Added & \\
\hline 2 & Availability of litigation for those projects & Selected & \\
\hline 3 & The role of the government in controlling and monitoring those projects & Selected & \\
\hline 4 & Finding solutions for the legal issues of the lands & Selected & \\
\hline 5 & Existence of programs by the government to deal with these projects & Modified & $\begin{array}{l}\text { Preparing a reconstruction program by } \\
\text { the government }\end{array}$ \\
\hline $\mathrm{F}$. & Economic factors & & \\
\hline 1 & Existence of funds & Selected & \\
\hline 2 & Existence of funds for long-term reconstruction & Modified & $\begin{array}{l}\text { Long term reconstruction has many } \\
\text { requirements which led to the complexity } \\
\text { when plan and develop for reconstruction }\end{array}$ \\
\hline 3 & Volume of the given funds & Selected & \\
\hline 4 & Volume of the destructed area & Selected & \\
\hline 5 & A period that needs for finding funding & Added & \\
\hline 6 & $\begin{array}{l}\text { A period that needs to make a disaster assessment to figure out the volume of } \\
\text { funds }\end{array}$ & Selected & \\
\hline 7 & Monitoring the funds until it reaches the target & Added & \\
\hline
\end{tabular}




\section{Civil Engineering Research Journal}

\begin{tabular}{|c|c|c|c|}
\hline 8 & Effective corporation between the donors and the organizations in the Gaza Strip & Selected & \\
\hline 9 & Effective disaster assessment to figure out the appropriate amount of funds & Selected & \\
\hline 10 & Price of material & Selected & \\
\hline 11 & Price of equipment & Selected & \\
\hline 12 & Price of manpower & Selected & \\
\hline 13 & Most of the funds don't include the reconstruction stage & Selected & \\
\hline G. & Duration factors & & \\
\hline 1 & Being as a heritage area & Selected & \\
\hline 2 & $\begin{array}{l}\text { Considering the development beside the humanitarian concerns in post disaster } \\
\text { reconstruction disaster }\end{array}$ & Selected & \\
\hline 3 & Considering the justice when giving the priority to reconstruct & Selected & \\
\hline 4 & $\begin{array}{l}\text { Finding appropriate land to reconstruct whenever the original land can't be } \\
\text { reconstructed }\end{array}$ & Selected & \\
\hline 5 & Efficiency in defining the responsibilities for every participant in these projects & Modified & $\begin{array}{l}\text { Who take the decisions with whom and } \\
\text { what sequences results of those decisions }\end{array}$ \\
\hline 6 & $\begin{array}{l}\text { Patience and not to impose pressure on employees who work on the } \\
\text { reconstruction projects by the beneficiaries }\end{array}$ & Modified & $\begin{array}{l}\text { Patience and not to impose pressure } \\
\text { on employees who work on the } \\
\text { reconstruction projects by the } \\
\text { beneficiaries }\end{array}$ \\
\hline
\end{tabular}

A pilot survey was established to measure the validity and reliability of the factors that have been extracted from the previous literature review with the help of expert engineers at the ministry of public works and housing in the Gaza Strip. Due to their experiences of reconstructing projects. 2 groups of engineers were formed. First group tested the validity of the questionnaire, and the degree of fitting to the main objective of the research. The second group tested the reliability factors. Some factors were deleted and others were added or modified depending on the Gaza Strip polices and formulations of reconstruction projects. It has been resulted 64 effective factors, which more reliable to the reality of the construction process in the Gaza Strip. Table 2 shows the results of the pilot study in editing the extracted factors.

Table 3: Cronbach's Coefficient Alpha for reliability (Ca). using reconstruction projects in the Gaza Strip. The questionnaire was distributed Depending on the definition of the "snow ball" one respondent was leading to another respondent until a group of respondents had been selected, due to the small sample size, which have an experience in reconstructing projects which consisted of the following (UNRWA, UNDP, Qatar committee, Ministries of the Gaza Strip, those ministries who have a direct relationship with reconstruction at the Gaza Strip, municipalities). Ninety (90) questionnaires were collected out of ninety-eight 98 questionnaires. Sixty-four factors were identified and categories to 7 main groups as the following (management, beneficiaries, international organizations, technic, government, economic and duration factors).

\begin{tabular}{|c|c|c|c|}
\hline No. & Fields & Cronbach's Alpha (C $\boldsymbol{\alpha})$ & 0.791 \\
\hline 1. & & Management factors & 0.670 \\
\hline 2. & & Factors related to participating in reconstruction projects (international organization) & 0.703 \\
\hline 3. & & Factors related to beneficiaries of reconstruction projects & 0.660 \\
\hline 4. & Technical factors & 0.864 \\
\hline 5. & Governmental factors & 0.839 \\
\hline 6. & Economic factors & 0.762 \\
\hline 7. & Duration factors & 0.925 \\
\hline
\end{tabular}

A five-point Likert scale had been used, respondents were required to choose a number were $(1=$ not important; $2=$ of little importance; 3 = somewhat important; 4 = important; and 5 = very important). Statical Package for social science (SPSS) was used to analyze the collected data. And to check the consistency and the probability of having same similar results Cronbach's coefficient alpha method had been used. The normal range of Cronbach's coefficient alpha $(\mathrm{C} \alpha)$ value is between 0.0 and +1 and the higher value reflects a higher degree of internal consistency $[39,40]$. The
Cronbach's coefficient alpha $(\mathrm{C} \alpha)$ was calculated for five fields. The results were in the range from 0.660 and 0.864 and the general reliability for all items equals 0.925 . This range is considered high, where it is above 0.7 . Thus, the result ensures the reliability of the questionnaire. Table 3 shows the Cronbach's Coefficient Alpha for reliability $(\mathrm{C} \alpha)$

The parametric statistical test is also needed and have been used to ensure that the data is following the normal distribution. Normality was assessed by applying the central limit theorem. 


\section{Civil Engineering Research Journal}

The central limit theorem states that when samples are large (above about 30), the sampling distribution will take the shape of a normal distribution, regardless of the shape of the population from which the sample was drawn Field [40]. The relative importance index (RII) was computed as Sambasivan \& Soon [41]. RII has been widely used in construction research for measuring attitudes with respect to surveyed variables. Several researches Enshassi et al. [42], Enshassi et al. [43], El-Hallaq \& Tayeh [44], Albhaisi et al. [45], Tayeh et al. [46], Tayeh et al. [47], Tayeh et al. [49], Tayeh et al. [50] used the RII in their analysis.

$$
\bar{X}_{W}=\frac{\sum W}{N}=\frac{5 n_{5}+4 n_{4}+3 n_{3}+2 n_{2}+1 n_{1}}{5 N}
$$

Where:

$\mathrm{W}=$ the weighting given to each factor by the respondents (ranging from 1 to 5 )

$A=$ the highest weight (i.e. 5 in this case)

$\mathrm{N}=$ the total number of respondents

The RII value had a range from 0 to 1 ( 0 not inclusive), the higher the value of RII, the more the impact of the attributes. Questionnaire tests were as the following:

\section{Results and Discussion}

By using SPSS software, data were analyzed. Cronbach's coefTable 4: Background information of respondents. ficient alpha method measures the reliability if the value is 0.9 or above, then it's a great reliability. High reliability is between 0.7 and 0.9 and if its between 0.5 to 0.7 then its moderate reliability. But low 0.5 means a poor value of reliability. The reliability of this research is great. 0.925 by using SPSS. The questionnaire data are acceptable. Normality was assessed by applying the central limit theorem. The central limit theorem states that when samples are large (above about 30), the sampling distribution will take the shape of a normal distribution, regardless of the shape of the population from which the sample was drawn [40]. According to that, the collected data of the research follow the normal distribution, where the sample size is $\mathrm{N}=90$ and so parametric tests must be used.

\section{Respondents information}

Table 4 shows the results of information of the respondents, where the highest result showed that $34.4 \%$ of the respondents were vice manager, $68.9 \%$ of them had a bachelor degree, $75.6 \%$ of them were from Gaza city, $44.44 \%$ of them worked at a government organizations, $71.1 \%$ of them have a high experiences, more than 5 years of experiences in reconstructing in the projects of 2008 and 2012 housing reconstruction projects, $68.9 \%$ of the respondents had an experience in of 2014 housing reconstruction projects and 57.8 of the respondents worked on projects with budget more than $\$ 10$ million.

\begin{tabular}{|c|c|c|}
\hline General Information & Frequency $(F)$ & Percent (\%) \\
\hline \multicolumn{3}{|l|}{ Job Title } \\
\hline GM manager & 19 & 24.4 \\
\hline Vice manager & 31 & 34.4 \\
\hline Site engineer & 22 & 21.1 \\
\hline Other & 18 & 20.0 \\
\hline \multicolumn{3}{|l|}{ Educational level } \\
\hline Bachelor & 62 & 68.9 \\
\hline Master & 24 & 26.7 \\
\hline Ph.D. & 1 & 1.1 \\
\hline Other & 3 & 3.3 \\
\hline \multicolumn{3}{|l|}{ Location } \\
\hline North Gaza & 8 & 8.9 \\
\hline Gaza & 68 & 75.6 \\
\hline Middle & 10 & 11.1 \\
\hline South & 4 & 4.4 \\
\hline \multicolumn{3}{|l|}{ Employer } \\
\hline Government sector & 40 & 44.44 \\
\hline Non-governmental organizations & 17 & 18.8 \\
\hline UNRWA & 21 & 23.3 \\
\hline Private sector & 10 & 11.11 \\
\hline Other & 2 & 2.2 \\
\hline \multicolumn{3}{|c|}{$\begin{array}{l}\text { Number of years of work in the reconstruction projects in the housing sector after the Israeli aggression } \\
\text { on the Gaza Strip in } 2008\end{array}$} \\
\hline 1 to less than 2 years & 3 & 3.3 \\
\hline
\end{tabular}




\section{Civil Engineering Research Journal}

\begin{tabular}{|c|c|c|}
\hline 2 to less than 3 years & 5 & 5.6 \\
\hline 3 to less than 5 years & 18 & 20.0 \\
\hline More than 5 & 64 & 71.1 \\
\hline \multicolumn{3}{|c|}{$\begin{array}{l}\text { Number of years of work in the reconstruction projects in the housing sector after the Israeli aggression } \\
\text { on the Gaza Strip in } 2014\end{array}$} \\
\hline 1 to less than 2 years & 4 & 4.4 \\
\hline 2 to less than 3 years & 4 & 4.4 \\
\hline 3 to less than 4 years & 20 & 22.2 \\
\hline 4 to 5 years & 62 & 68.9 \\
\hline \multicolumn{3}{|c|}{$\begin{array}{l}\text { The cost of the projects in which it worked and specialized in the reconstruction of the housing sector } \\
\text { after the Israeli aggression on the Gaza Strip in } 2014\end{array}$} \\
\hline$>\$ 1$ million & 4 & 4.4 \\
\hline From $\$ 1$ to less $\$ 5$ million & 12 & 13.3 \\
\hline From $\$ 5$ to less $\$ 10$ million & 22 & 24.4 \\
\hline$\$ 10$ million and more & 52 & 57.8 \\
\hline
\end{tabular}

Discussion of the respondents' information: The results show that the distribution of the questionnaire was well distributed while the respondents were as the research desired, the respondent have different experiences, so the respondents were between site engineers, managers and vice managers. But the most of those who have been replied to this questionnaire, were having a bachelor's degree, less were having master's degree and that hasn't a relation with the efficiency of the answers because the answers we need depends on experience not about higher degrees. Gaza city was the highest respondent's place and this shows that most enterprises and most institutions are located in Gaza City, this is due to the status of Gaza City as if it is the capital of the Gaza Strip. Government institutions were the highest answers, because reconstruction projects are mainly carried out through official bodies. The results showed extensive experience in this

Table 5: Factors affecting reconstruction.

\begin{tabular}{|c|c|c|c|c|c|c|c|}
\hline No. & Items & Mean & $\begin{array}{l}\text { Std. } \\
\text { dev. }\end{array}$ & RII (\%) & $\begin{array}{c}\text { T } \\
\text { value }\end{array}$ & $\begin{array}{l}\text { P value } \\
\text { Sig. }\end{array}$ & Rank \\
\hline \multicolumn{8}{|c|}{ Management factors } \\
\hline A1 & The efficiency of management process in the organization & 3.87 & 0.67 & 77.33 & 12.20 & 0.000 & 8 \\
\hline $\mathrm{A} 2$ & $\begin{array}{l}\text { The management of housing reconstruction after disasters should keep } \\
\text { going, with the existence of the built environment when planning }\end{array}$ & 3.73 & 0.75 & 74.67 & 9.32 & 0.000 & 11 \\
\hline A3 & $\begin{array}{l}\text { The management of housing reconstruction after disasters should consider } \\
\text { the delay of the process for different reasons when planning }\end{array}$ & 3.91 & 0.86 & 78.22 & 10.09 & 0.000 & 5 \\
\hline A4 & Adaptive Capacity of the area of housing reconstruction when planning & 3.96 & 0.54 & 79.11 & 16.83 & 0.000 & 3 \\
\hline A5 & $\begin{array}{l}\text { Tacking in account the vulnerability of the environment of housing recon- } \\
\text { struction is a factor for a good management process }\end{array}$ & 3.88 & 0.75 & 77.56 & 11.15 & 0.000 & 7 \\
\hline A6 & Being ready for management process when it needs & 3.96 & 0.69 & 79.11 & 13.22 & 0.000 & 4 \\
\hline A7 & $\begin{array}{l}\text { Risk mitigation should be as a priority when managing housing reconstruc- } \\
\text { tion projects }\end{array}$ & 3.46 & 0.93 & 69.11 & 4.67 & 0.000 & 15 \\
\hline A8 & $\begin{array}{c}\text { Efficiency of the assessment of the requirement for post disaster reconstruc- } \\
\text { tion }\end{array}$ & 3.82 & 0.71 & 76.44 & 10.95 & 0.000 & 10 \\
\hline A9 & The existence of the material of the reconstruction & 3.61 & 0.91 & 72.22 & 6.38 & 0.000 & 13 \\
\hline A10 & The good Corporation between organizations & 3.49 & 1.01 & 69.78 & 4.60 & 0.000 & 14 \\
\hline A11 & The good Corporation between the basic resources of the reconstruction & 3.86 & 0.73 & 77.11 & 11.16 & 0.000 & 9 \\
\hline A12 & Emergency plans to support the management of the reconstruction & 3.99 & 0.66 & 79.78 & 14.17 & 0.000 & 2 \\
\hline
\end{tabular}

field through the emergence of high results on the experience of more than five years in the field of this type of projects in addition to a huge budget in this type of projects.

Factors affecting reconstruction projects: The second section of the questionnaire contains 7 factors, each factor contains a number of items, Management factors (15 items), Factors related to participating in reconstruction projects ( 8 items), Factors related to beneficiaries of reconstruction projects (5 items), Technical factors (12 items), Government factors (5 items), Economic factors (13 items), and Duration factors ( 6 items). These statements were subjected to the views of respondents, and the outcomes of the analysis were shown in Table 5. The descriptive statistics, i.e. Means, Standard Deviations (SD), t-value (two tailed), probabilities (P-value), Relative Importance Indices (RII), and finally ranks were established. 


\section{Civil Engineering Research Journal}

\begin{tabular}{|c|c|c|c|c|c|c|c|}
\hline A13 & The existence of special management mechanism for such a project & 3.88 & 0.67 & 77.56 & 12.48 & 0.000 & 6 \\
\hline A14 & Efficiency of the management of the government & 4.04 & 0.63 & 80.89 & 15.62 & 0.000 & 1 \\
\hline A15 & Differences in politics of the reconstruction between different organizations & 3.72 & 0.82 & 74.44 & 8.34 & 0.000 & 12 \\
\hline \multicolumn{8}{|c|}{ Factors related to institutions participating (international organization) in reconstruction projects } \\
\hline B1 & Differences in experience between the participants specially the engineers & 4.14 & 0.91 & 82.89 & 11.98 & 0.000 & 1 \\
\hline B2 & Support sustainable mechanism & 3.62 & 0.79 & 72.44 & 7.50 & 0.000 & 8 \\
\hline B3 & Differences of the working manpower & 3.87 & 0.75 & 77.33 & 10.93 & 0.000 & 6 \\
\hline B4 & Being aware of the importance of applying sustainability & 3.77 & 0.72 & 75.33 & 10.11 & 0.000 & 7 \\
\hline B5 & Understanding the legislation and policies by engineers in the area & 3.97 & 0.63 & 79.33 & 14.65 & 0.000 & 4 \\
\hline B6 & Effort of working hard by every participant & 3.89 & 0.71 & 77.78 & 11.87 & 0.000 & 5 \\
\hline B7 & Having a good practice to manage any issue of the reconstruction & 4.10 & 0.81 & 82.00 & 12.92 & 0.000 & 2 \\
\hline B8 & Planning for post disaster risk reduction in the future & 4.00 & 0.82 & 80.00 & 11.55 & 0.000 & 3 \\
\hline \multicolumn{8}{|c|}{ Factors related to beneficiaries of reconstruction projects } \\
\hline $\mathrm{C} 1$ & The volume of those who are in need for these projects (Beneficiaries) & 4.17 & 0.86 & 83.33 & 12.80 & 0.000 & 1 \\
\hline $\mathrm{C} 2$ & Psychological situation & 3.72 & 0.94 & 74.44 & 7.32 & 0.000 & 3 \\
\hline C3 & Gab of information due to the weakness of incorporation of the beneficiaries & 3.47 & 1.12 & 69.33 & 3.94 & 0.000 & 5 \\
\hline $\mathrm{C} 4$ & Availability of the temporary houses till the reconstruction finishes & 3.68 & 0.95 & 73.56 & 6.80 & 0.000 & 4 \\
\hline $\mathrm{C} 5$ & Fitting between donors' condition and the needs of the beneficiaries & 4.12 & 0.56 & 82.44 & 19.10 & 0.000 & 2 \\
\hline \multicolumn{8}{|c|}{ Technical factors } \\
\hline D1 & Volume of the destruction of a building & 4.23 & 0.70 & 84.67 & 16.62 & 0.000 & 2 \\
\hline D2 & The amount of landfill resulting from the disaster & 3.76 & 0.74 & 75.11 & 9.70 & 0.000 & 8 \\
\hline D3 & Number of the destructed houses & 4.40 & 0.72 & 88.00 & 18.56 & 0.000 & 1 \\
\hline D4 & Efficiency and the quality of the work when reconstruct & 4.18 & 0.77 & 83.56 & 14.46 & 0.000 & 3 \\
\hline D5 & The efficiency of the infrastructure when start the work of reconstructing & 3.82 & 0.95 & 76.44 & 8.17 & 0.000 & 6 \\
\hline D6 & Efficiency of preliminary assessment & 4.00 & 0.70 & 80.00 & 13.49 & 0.000 & 4 \\
\hline D7 & Applying safety when reconstruct & 3.28 & 0.97 & 65.56 & 2.71 & 0.000 & 12 \\
\hline D8 & $\begin{array}{c}\text { Existence of the resources of the reconstruction process such as material, } \\
\text { equipment and manpower }\end{array}$ & 3.64 & 0.83 & 72.89 & 7.41 & 0.000 & 9 \\
\hline D9 & Integration of information about the process of these projects & 3.81 & 0.73 & 76.22 & 10.50 & 0.000 & 7 \\
\hline D10 & The requirement of the donors doesn't fit with the local environment & 3.63 & 0.87 & 72.67 & 6.93 & 0.000 & 10 \\
\hline D11 & Existence of the quality and quantity of materials & 3.89 & 1.04 & 77.78 & 8.08 & 0.000 & 5 \\
\hline D12 & Electricity availability & 3.42 & 0.97 & 68.44 & 4.12 & 0.000 & 11 \\
\hline \multicolumn{8}{|c|}{ Government factors } \\
\hline E1 & The effective role of municipality & 3.71 & 0.88 & 74.22 & 7.69 & 0.000 & 2 \\
\hline E2 & Availability of litigation for those projects & 3.43 & 1.03 & 68.67 & 4.00 & 0.000 & 5 \\
\hline E3 & The role of the government in controlling and monitoring those projects & 3.56 & 1.07 & 71.11 & 4.92 & 0.000 & 4 \\
\hline $\mathrm{E} 4$ & Finding solutions for the legal issues of the lands & 3.64 & 0.88 & 72.89 & 6.96 & 0.000 & 3 \\
\hline E5 & Existence of programs by the government to deal with these projects & 3.87 & 0.74 & 77.33 & 11.15 & 0.000 & 1 \\
\hline \multicolumn{8}{|c|}{ Economic factors } \\
\hline $\mathrm{F} 1$ & Existence of funds & 3.82 & 1.12 & 76.44 & 6.98 & 0.000 & 7 \\
\hline $\mathrm{F} 2$ & Existence of funds for long-term reconstruction & 4.01 & 0.84 & 80.22 & 11.40 & 0.000 & 5 \\
\hline F3 & Volume of the given funds & 4.04 & 0.81 & 80.89 & 12.29 & 0.000 & 4 \\
\hline $\mathrm{F} 4$ & Volume of the destructed areas & 4.14 & 0.79 & 82.89 & 13.80 & 0.000 & 2 \\
\hline F5 & A period that needs for finding funding & 3.90 & 0.85 & 78.00 & 10.06 & 0.000 & 6 \\
\hline F6 & $\begin{array}{l}\text { A period that needs to make a disaster assessment to figure out the volume } \\
\text { of funds }\end{array}$ & 3.57 & 0.87 & 71.33 & 6.15 & 0.000 & 9 \\
\hline F7 & Monitoring the funds until it reaches the target & 3.71 & 0.85 & 74.22 & 7.93 & 0.000 & 8 \\
\hline F8 & $\begin{array}{l}\text { Effective cooperation between the donors and the organizations in the Gaza } \\
\text { Strip }\end{array}$ & 4.12 & 0.60 & 82.44 & 17.85 & 0.000 & 3 \\
\hline
\end{tabular}




\section{Civil Engineering Research Journal}

\begin{tabular}{|c|c|c|c|c|c|c|c|}
\hline F9 & Effective disaster assessment to figure out the appropriate amount of funds & 4.23 & 0.72 & 84.67 & 16.26 & 0.000 & 1 \\
\hline F10 & Price of material & 3.43 & 0.81 & 68.67 & 5.09 & 0.000 & 13 \\
\hline F11 & Price of equipment & 3.44 & 0.86 & 68.89 & 4.89 & 0.000 & 12 \\
\hline F12 & Price of manpower & 3.48 & 0.82 & 69.56 & 5.50 & 0.000 & 11 \\
\hline F13 & Most of the funds don't include the reconstruction stage & 3.56 & 0.77 & 71.11 & 6.88 & 0.000 & 10 \\
\hline \multicolumn{8}{|c|}{ Duration factors } \\
\hline G1 & Being as a heritage area & 3.79 & 0.95 & 75.78 & 7.85 & 0.000 & 4 \\
\hline G2 & $\begin{array}{l}\text { Considering the development beside the humanitarian concerns in post } \\
\text { disaster reconstruction disaster }\end{array}$ & 3.76 & 0.89 & 75.11 & 8.05 & 0.000 & 5 \\
\hline G3 & Considering the justice when giving the priority to reconstruct & 3.94 & 0.78 & 78.89 & 11.43 & 0.000 & 2 \\
\hline G4 & $\begin{array}{l}\text { Finding appropriate land to reconstruct whenever the original land can't be } \\
\text { reconstructed }\end{array}$ & 3.87 & 0.77 & 77.33 & 10.72 & 0.000 & 3 \\
\hline G5 & $\begin{array}{c}\text { Efficiency in defining the responsibilities for every participant in these } \\
\text { projects }\end{array}$ & 4.10 & 0.74 & 82.00 & 14.20 & 0.000 & 1 \\
\hline \multirow[t]{2}{*}{ G6 } & $\begin{array}{l}\text { Patience and not to impose pressure on employees who work in the recon- } \\
\text { struction projects by the beneficiaries }\end{array}$ & 3.60 & 1.10 & 72.00 & 5.18 & 0.000 & 6 \\
\hline & All statements & 3.82 & 0.35 & 76.40 & 22.44 & 0.000 & \\
\hline
\end{tabular}

The results illustrated that the total average means for all items equal 3.82, T-test 22.44 and the P-value equal 0.000 which is less than 0.05 . This means that the respondents have strong agreement on the terms relating to the factors affecting reconstruction. The SD was also used to quantify the amount of variation or dispersion of respondent opinions regarded to "the factors affecting reconstruction, the average SD was 0.35 , which indicate that the respondent's results are consistent and are not spread out over a wider range of values. P-value $=0.000<0.05$, and T statistics (22.44)>T critical (1.98), so, there is a statistically significant difference attributed to the respondent's opinions at the level of $\alpha \leq 0.05$ between the statistical mean (3.82) and hypotheses mean (3) of the fields.

\section{Group one: management factors}

Influencing factors: The most influenced factor in the management group is "efficiency of the management of the government". Government of the Gaza Strip is very sensitive to the situation and very supportive in facilitating the reconstruction process, and that can be seen easily around and by the witnesses of the beneficiaries and the international organizations such giving license easily, this result agrees with Sharma et al. [9], this also fits with Ophiyandri et al. [30] who said that government's role and support can have a serious role in the process of reconstructing. This means that the first influencing factor that can really support the process is the government itself by being strong enough to handle all the needed phases. The next influencing factor is " having an emergency plan", the results also agree with von Meding et al. [35] who, supported having a planned management and groups to reduce the barrier which will decrease the efficiency of reconstructing.

\section{Group Two: Factors related to participating (interna- tional organizations) in reconstruction projects}

Influencing factors: "Differences in experience between the participants (engineers for example)" is a supportive factor of housing reconstructing in the organizations group. The Gaza Strip full of different college majors which can facilitate the applying this factor in organizations. Agrees with von Meding et al. [35] stated, who said that different participants with different experience will support the process of reconstructing. Issues and sudden problem can be solved by those different skills. "Having a good practice to manage any issue of the reconstruction" is a second important factor. Agrees with (Bilau et al. [34] and Ophindari [30].

\section{Group Three: Factors related to beneficiaries of recon- struction projects}

Influencing factors: The results indicate that all of the factors related to beneficiaries of reconstruction projects in this group are barriers factors, which affect the process of reconstruction negatively. The findings were indicated that the higher rank as a challenged factor is "number of those who are in need for the reconstruction projects (Beneficiaries)". Which means whenever there are less destructive buildings would be better. More funds are needed when more buildings need a construct [14]. Second factor which considered as a challenging factor is the "Fitting between the condition and the needs of the beneficiaries", a small interview to support the answers with the managers of the ministry of public work and housing confirm that less conditions by donors can increase the efficiency of the reconstruction process. There are some of reconstructed places had been designed and implemented under the conditions of their donors, which isn't that applicable in the Gaza Strip, and couldn't fit with the demands of the beneficiaries.

\section{Group Four: Technical factors}

Influencing factors: The findings indicated that "Number of the destructed houses" is the highest rank. But it's supposed to be considered as a challenged factor while it's not a factor we can control. Less numbers of destructive houses can lead to more effective work in reconstructing, by giving a higher chance for the 
buildings to have better rehabilitation, but by the increase of the destructive houses the chance should be divided so justice can reach the beneficiaries. Which the same of what Subekti [14] stated. The second highest factor is similar to the previous "Volume of the destruction of a building" at every unit of the destructed units how much destruction is in there, is it greatly damaged or partially damaged. It considers as challenging factor, and it can't be controlled. Less destructive units are more desired for an easy, efficient and quick reconstruction.

\section{Group Five: Governmental factors}

Influencing factors: The results also revealed that "existence of programs by the government to deal with these projects" and also the "effective role of municipality" as the greatest influencing factors. Another role of the government is the role of municipal, integration in format and services between local government organization leads to effective reconstruction process in the projects. From reality, international organizations had established that municipalities had a great role in facilitating the process of housing reconstruction.

\section{Group Six: Economical factors}

Influencing factors: "Effective disaster assessment to figure out the appropriate amount of funds": Assessment is the key to reach the efficiency in reconstructing, assessment lead to the appropriate amount of funds needed in addition to preparing the methodology of reconstructing. Field et al. [40]; Fengler et al. [50] confirmed the importance of assessment is to approximate the appropriate funds. And also Aufret et al. [51] supported the idea of the importance of having an effective assessment to have affected reconstructing. And as a barrier is the "Volume of destructive areas". Rotimi et al. [7] established that the area of destruction is the key role of having efficient reconstructing. Volume of destructed Areas will determine the appropriate funds. Due to the increase of the demands in reconstructing huge areas of destruction efficiency will be reduced due to the great pressure the team will have, and great destructed areas need a great amount of funds and so on.

\section{Group Seven: Duration factors}

Influencing factors: "Efficiency in defining the responsibilities for every participant in these projects". One of the effective factors that can reduce the period of reconstruction, so the time can be more effective when reconstructing is defining the responsibilities for each participant. Khalid et al. [31] stated that defining who take the decisions, with whom and what sequences resulted of those decisions, with whom and what sequences resulted of those decisions. Agrees with Tafti \& Tomlinson [48]. "Considering the justice when giving the priority to reconstruct": Karunasena \& Rameezdeen [21] established that are submitting justice distributions of housing recovery can save time. The people of the Gaza Strip had different chances, depending on equity not equality, every beneficiary had his own chance of registration for housing reconstruction.

\section{Summary of factors affecting reconstruction in the housing sector}

Table 6: Rank of the factors.

\begin{tabular}{|c|c|c|}
\hline Factors & Average RII & Rank \\
\hline Factors related to institutions participating in reconstruction projects & 78.39 & 1 \\
\hline Duration factors & 76.85 & 2 \\
\hline Technical factors & 76.78 & 3 \\
\hline Factors related to beneficiaries of reconstruction projects & 76.62 & 4 \\
\hline Management factors & 76.22 & 5 \\
\hline Economic factors & 76.10 & 6 \\
\hline Governmental factors & 72.84 & 7 \\
\hline
\end{tabular}

Table 6 illustrates rank of the factors. The results show that the most effective group of factors that affect the efficiency of the housing reconstruction projects is the role of the international organizations. But the less influencing group is the role of the government. But all of the groups are efficient and have affection in the process of housing reconstructions, Results show that the affection is almost similar to the other groups.

Respondents were asked to give a rank for each question in scale 1 to 5 . They were informed that the second part of the questionnaire on factors affecting the reconstruction of the housing sector in the Gaza Strip contained seven sections. Each section has a different impact on this type of project based on the pilot study, and each department will have its own properties. Data were then collected and analyzed using the SPBS program. Relative import- ant index (RII) used as a tool to rank the factors. Some factors have had a positive impact on increased efficiency in reconstruction, but some have had a negative impact on efficiency. Some of these factors can be controlled, but others are beyond manual control. From each section two factors had been extracted as the highest influencing factors in the reconstruction process in the Gaza Strip after the 2014 conflict. Sixteen factors were ranked is the highest important factors from 46 factors. Table 7 shows the important factors that affect the reconstruction in the Gaza Strip after the 2014 conflict. In addition, the most important group that affect the reconstruction process in the Gaza Strip were the factor related to the institution's participation and in there we mean mostly the international organization in the Gaza Strip which include the following factors [52]. 


\section{Civil Engineering Research Journal}

i. Differences in experience between the participants specially the engineers
ii. Support sustainable mechanism
iii. Differences of the working manpower

iv. Being a war of the importance of applying sustainability

v. Understanding the legislation and policies by engineers in the area

\section{vi. Effort of working hard by every participant}

vii. Having a good practice to manage any issue of the reconstruction

viii. Planning for post disaster risk reduction in the future and the other group's results were around each other, means have the same efficiency at the reconstruction projects. But the results show that governmental factors have the lowest degree of ranking.

\section{Conclusion}

In this research, the questionnaire was used to reach the desired results in finding the most important factors affecting the reconstruction of the Gaza Strip. Accordingly, 46 factors have been subdivided into 7 sections, as reconstruction has many supporting parties and phases that have a real role in project implementation. The study found that the factors influencing the work of international institutions are the most important factor in the Table 7: the important factors that affect the reconstruction in the Gaza reconstruction process in the Gaza Strip, and that the factors affecting the government's work are the least influential. It should, therefore, shed light on the factors affecting the effective functioning of international institutions as the following: differences in experience between the participants specially the engineers, support sustainable mechanism, differences of the working manpower, being a aware of the importance of applying sustainability, understanding the legislation and policies by engineers in the area, effort of working hard by every participant, having a good practice to manage any issue of the reconstruction and planning for post disaster risk reduction in the future.

So, the success and effectiveness of reconstruction projects in the Gaza Strip can be achieved through which financial and preventive losses can be reduced. Without forgetting a main factors that had a great influencing on the reconstruction process for the other groups. It is necessary to focus on these points by institutions and stakeholders for more efficient work when reconstruct, and these important factors are having efficiency of the management of the government, emergency plans by the parties who concern of reconstructing the Gaza Strip, fitting between donors conditions and beneficiaries' needs, prepared program by the government to deal with these projects, effective role of municipality, effective disaster assessment to figure out the appropriate amount of funds, efficiency in defining the responsibilities for every participant in these projects and considering the justice when giving the priority to reconstruct to the beneficiaries. Some suggestions can be followed as suggested in Table 7.

2014 conflict.

\begin{tabular}{|c|c|c|c|c|}
\hline & Factors & Group & Notes & Suggestion \\
\hline i. & $\begin{array}{l}\text { Efficiency of government man- } \\
\text { agement }\end{array}$ & $\begin{array}{l}\text { Management } \\
\text { factors }\end{array}$ & $\begin{array}{l}\text { Supportive factor. Whenever there is } \\
\text { an efficient government role in man- } \\
\text { agement efficiency in the reconstruc- } \\
\text { tion will appear }\end{array}$ & $\begin{array}{l}\text { Government can make courses about man- } \\
\text { agement issues to their staff }\end{array}$ \\
\hline ii. & $\begin{array}{l}\text { The existence of an emergency } \\
\text { plan }\end{array}$ & $\begin{array}{l}\text { Management } \\
\text { factors }\end{array}$ & $\begin{array}{l}\text { Supportive factor. Emergency plans } \\
\text { can mitigate risk when reconstruct }\end{array}$ & $\begin{array}{l}\text { Emergency plans should be prepared by } \\
\text { every section and every party of the recon- } \\
\text { struction projects in the Gaza Strip }\end{array}$ \\
\hline iii. & $\begin{array}{l}\text { Differences in experience among } \\
\text { participants (engineers for } \\
\text { example) }\end{array}$ & $\begin{array}{l}\text { Factors belong } \\
\text { to international } \\
\text { organizations }\end{array}$ & $\begin{array}{l}\text { Supportive factor. Different experi- } \\
\text { ence means different issues can be } \\
\text { solved efficiently }\end{array}$ & $\begin{array}{l}\text { The organizations and companies who } \\
\text { concern of reconstruction the Gaza Strip } \\
\text { should employ different experience }\end{array}$ \\
\hline iv. & $\begin{array}{l}\text { Having a good practice to man- } \\
\text { age any issue for reconstruction }\end{array}$ & $\begin{array}{l}\text { Factors belong } \\
\text { to an interna- } \\
\text { tional organi- } \\
\text { zation }\end{array}$ & $\begin{array}{l}\text { Supportive factor. Efficient practice } \\
\text { equal efficient reconstructing }\end{array}$ & $\begin{array}{c}\text { The organizations who concern of recon- } \\
\text { structing the Gaza Strip should employ } \\
\text { those who has productivity and efficiency } \\
\text { in their work }\end{array}$ \\
\hline.$v$ & $\begin{array}{l}\text { Number of people in need of } \\
\text { reconstruction projects (benefi- } \\
\text { ciaries) }\end{array}$ & $\begin{array}{l}\text { Factors belong } \\
\text { to the benefi- } \\
\text { ciaries }\end{array}$ & $\begin{array}{l}\text { Challenging factor. Less people in } \\
\text { need lead to efficiency and to perfect } \\
\text { productivity }\end{array}$ & $\begin{array}{l}\text { It's not a factor that we can control, it } \\
\text { results from the conflict randomly and } \\
\text { most of the time results a great amount of } \\
\text { beneficiaries }\end{array}$ \\
\hline vi. & $\begin{array}{l}\text { Financing conditions with the } \\
\text { needs of the beneficiaries }\end{array}$ & $\begin{array}{l}\text { Factors belong } \\
\text { to the benefi- } \\
\text { ciaries }\end{array}$ & $\begin{array}{l}\text { Challenging factor. Conditions of the } \\
\text { donors should fit with the needs of } \\
\text { beneficiaries and the conditions of } \\
\text { the Gaza Strip }\end{array}$ & $\begin{array}{l}\text { It's not a factor that we can control, but } \\
\text { some simple solution may be done, a } \\
\text { proposal for donors should contain some } \\
\text { of the Gaza Strip regulations in addition to } \\
\text { explaining the beneficiaries' needs. }\end{array}$ \\
\hline vii. & Number of the destructed houses & $\begin{array}{l}\text { Technical } \\
\text { factors }\end{array}$ & Challenging factor. & $\begin{array}{l}\text { It's not a factor that we can control, it } \\
\text { results from the conflict randomly and } \\
\text { most of the time results a great amount of } \\
\text { destructed houses }\end{array}$ \\
\hline
\end{tabular}




\section{Civil Engineering Research Journal}

\begin{tabular}{|c|c|c|c|c|}
\hline viii. & $\begin{array}{l}\text { Volume of the destruction of a } \\
\text { building }\end{array}$ & $\begin{array}{l}\text { Technical } \\
\text { factors }\end{array}$ & Challenging factor. & $\begin{array}{l}\text { It's not a factor that we can control, it re- } \\
\text { sults from the conflict randomly and most } \\
\text { of the time results a great volume of the } \\
\text { destruction of a building }\end{array}$ \\
\hline ix. & $\begin{array}{l}\text { Existence of programs by the } \\
\text { government to deal with these } \\
\text { projects }\end{array}$ & $\begin{array}{l}\text { Governmental } \\
\text { factors }\end{array}$ & $\begin{array}{l}\text { Supportive factor. Preparation of a } \\
\text { pre-plan for this type of projects by } \\
\text { the government for ease of imple- } \\
\text { mentation and speed and minimize } \\
\text { losses as possible while reducing the } \\
\text { time required }\end{array}$ & $\begin{array}{l}\text { Prepare pre-plan by the government espe- } \\
\text { cial for these kind of projects }\end{array}$ \\
\hline $\mathrm{x}$. & Effector role of the municipality & $\begin{array}{l}\text { Governmental } \\
\text { factors }\end{array}$ & $\begin{array}{c}\text { Supportive factor. The municipality } \\
\text { is considered a cornerstone of recon- } \\
\text { struction. Their role is important and } \\
\text { necessary }\end{array}$ & $\begin{array}{l}\text { The municipality should do courses } \\
\text { for their staff to a warn them of their } \\
\text { important role in these projects, and their } \\
\text { affection on projects and beneficiaries. }\end{array}$ \\
\hline xi. & Effective disaster assessment & $\begin{array}{l}\text { Economical } \\
\text { factors }\end{array}$ & $\begin{array}{l}\text { Supportive factor. Re-Evaluation of } \\
\text { damage affects all reconstruction } \\
\text { tasks such as budget and scheduling }\end{array}$ & $\begin{array}{l}\text { The damage assessment staff should be } \\
\text { employed with high efficiency }\end{array}$ \\
\hline xii. & Size of destroying areas & $\begin{array}{l}\text { Economical } \\
\text { factors }\end{array}$ & $\begin{array}{l}\text { Challenged factor. The greater the } \\
\text { damage, the greater the need for } \\
\text { reconstruction, which increased the } \\
\text { required financing for reconstruction }\end{array}$ & $\begin{array}{l}\text { It's not something can be controlled; } \\
\text { conflict results a lot of damage and it's } \\
\text { not something can be assumed or can be } \\
\text { mitigated. }\end{array}$ \\
\hline xiii. & $\begin{array}{l}\text { Efficiency in determining respon- } \\
\text { sibilities for each participant in } \\
\text { these projects }\end{array}$ & Period factors & $\begin{array}{l}\text { Supportive factor. The identification } \\
\text { and distribution of tasks correctly } \\
\text { reduce many losses, especially it can } \\
\text { shortage the period of reconstructing. }\end{array}$ & $\begin{array}{l}\text { The senior management of institutions } \\
\text { responsible for reconstruction must use } \\
\text { staff according to their qualifications and } \\
\text { employ staff in their proper place. Distrib- } \\
\text { uted according to an appropriate schedule. }\end{array}$ \\
\hline viv. & $\begin{array}{l}\text { Consider justice when prioritiz- } \\
\text { ing reconstruction }\end{array}$ & Period factors & $\begin{array}{l}\text { The fair and appropriate distribution } \\
\text { of reconstruction opportunities to } \\
\text { beneficiaries reduces much of the } \\
\text { conflict that leads to the loss of time. } \\
\text { And to identify correct priorities } \\
\text { among beneficiaries. }\end{array}$ & $\begin{array}{l}\text { Institutions responsible for distributing } \\
\text { reconstruction opportunities among } \\
\text { beneficiaries should define a system of pri- } \\
\text { oritization so that they can be implement- } \\
\text { ed more easily }\end{array}$ \\
\hline
\end{tabular}

\section{References}

1. Enshassi A, Chatat T, Meding JV, Farino F (2017) Factors influencing post-disaster reconstruction project management for housing provision in the Gaza Strip, Occupied Palestinian Territories. Disaster Risk Science Journal 8: 402-414

2. Ismail D, Majid T, Roosli R (2017) Analysis of variance of the effects of a project's location on key issues and challenges in post-disaster reconstruction projects. Journal of economics 5(46): 1-13.

3. Abulnour AH (2013) Toconflictds efficient disaster management in Egypt. Housing and Building National Research Center Journal 10: 117-126.

4. General Directorate of Customs Security (2011) Monthly reports.

5. MPWH Ministry of Public Works and Housing (2011) monthly report of the ministry.

6. Euro-MED (2014) Euro- Mediterranean Human Rights Monitor 2014 Report of Euro.

7. Rotimia JOB, Masuriera JL, Wilkinson S (2006) The Regulatory Framework for Effective Post Disaster Reconstruction in New Zealand.

8. Chang Y (2012) Resourcing for post-disaster housing reconstruction. Degree of Doctor of Philosophy in Civil Engineering, The University of Auckland, New Zealand.

9. Sharma K, Subedi M, Pokharel B (2017) Post disaster reconstruction after 2015 gorkha earthquake: challenges and influencing factors. Journal Institute of Engineering13(1): 67-78.

10. Sadiqi Z, Coffey V, Trigunarsyah B (2011) Post-disaster housing reconstruction: Challenges for Community Participation.
11. Vijekumara A, Karunasena G (2016) Analysis on resettlement process: landslide Disasters in Sri Lanka. Conference: $12^{\text {th }}$ International Conference on the International Institute for Infrastructure Resilience and Reconstruction, Kandy, Sri Lanka.

12. Maheshiks BA, Sangasumana RP (2017) Issues and challenges of post landslide management in sri lanka a case study of meeriyabedda landslide in badulla district. International Journal of Scientific and Research Publications7: 215-225.

13. Salvatore S (2003) Financing and aid management arrangements In Post-Conflict Situations.

14. Subekti A (2008) Delivering results in post-disaster recovery through effective financial management: The Case of Aceh and Nias. In: international disaster and risk conference, 25-29 august 2008, Davos, Switzerland.

15. Nissanka WK, Karunasena G, Rameezdeen R (2008) Study of factors affecting post disaster housing reconstruction. In: International Conference in Building Education and research, heritance Kandalama, Sri lanka.

16. Artiningshi, Setyono JS, Yuniartanti RK (2016) The challenges of disaster governance in an indonesian multi hazards city: a case of semarang, central java. cities 2015 International Conference, Intelligent Planning Toconflictds Smart Cities,Surabaya, Indonesia.

17. Central Emergency Relief Organization (2004) Disaster management for student, managing disasters, Barbados.

18. Kawata Y (2001) Disaster mitigation due to next Nankai earthquake tsunamis occurring in around 2035. Kyoto University, Kyoto, Japan

19. Kusky TM (2003) Geological hazards: A Sourcebook, Greenwood Press, Westport, CT, USA, pp. 312 


\section{Civil Engineering Research Journal}

20. RADA Reconstruction and Development Agency (2006) Post Tsunami Recovery and Reconstruction, December 2006. Colombor, Italy, p. 1-66.

21. Karunasena G, Rameezdeen R (2010) Post disaster housing reconstruction: Comparative study of donor vs owner-driven approaches International Journal of Disaster Resilience in the Built Environment 1: $173-191$.

22. Hidayat B, Egbu CO (2010) Literature review of the project management in post disaster reconstruction. $6^{\text {th }}$ Annual Arcom Conference, leeds, UK.

23. Baradan B (2006) The role of information and communication technologies in the process of post disaster Housing Reconstruction. In: $1^{\text {s }}$ international cib endorsed metu postgraduate conference: built environment and information technologies, Ankara, Turkey. p.73-84

24. IftekharA (2011) An overview of post-disaster permanent housing reconstruction in developing countries. International Journal of Disaster Resilience in the Built Environment 2 (2): 148-164.

25. Chang Y, Wilinson S, Brunsdon D, Seville E, Potangaroa R (2011) An integrated approach: managing resources for post-disaster reconstruction. Journal of Disasters 35: 739-769.

26. Ismail D, Majid T, Roosli R, Samah N (2014) Project management success for post-disaster reconstruction projects: International NGOs. Perspectives. Procedia Economics and Finance 18:120-127.

27. Amnesty international (2006) Israel/Gaza operation 'Cast lead':22 Days of Death and destruction. Report of Amnesty International. London, United Kingdom.

28. Chang Y, Wilkinson S, Seville E, Potangaroa R (2010) Resourcing for a resilient post-disaster reconstruction environment. International Journal of Disaster Resilience in The Built Environment1(1): 65-83.

29. Kitamato A, Andaroodi E, Matini MR, Ono K (2011) Post disaster reconstruction of citadel of Bam, Iran.

30. Ophiyandri T, Amaratunga D, Pathriage CH, Keraminiyage K (2013) Critical success factors for community-based post-disaster housing reconstruction projects in the pre-construction stage in Indonesia. Disaster Resilience in The Built Environment Journal4 (2): 236-249.

31. Khalid KN, Nifa FAA, Ismail RM, Lin CK (2017) Initial findings on delay factors in the post-disaster housing reconstruction: local authorities and NGOs perspectives. Journal Of Engineering Science And Technology12(4): 137-146.

32. Tafti MT, Tomlinson R (2018) Theorizing distributive justice and the practice of post disaster housing recovery.

33. Ibrahim M (2010) Post-disaster housing reconstruction in a conflict affect district, batticaloa, Sri lanka: reflecting on the climate smart disaster risk management approach. strengthening climate resilience, institute of development studies at the university of Sussex Brighton, UK

34. Bilau A, Witt E, Lill I (2015) A framework for managing post-disaster housing reconstruction. Procedia Economics and Finance 21: 331-320.

35. von Meding J, Wong S, Kanjanabootra M, Taheri T (2016) Competence-based system development for post-disaster project management. Disaster prevention and management 25(3): 375-394.
36. Rani W, Nifa F, Ismail MN, Khalid KN (2017) Planning for Post Disaster Recovery: Lesson Learnt from Flood Events in Kelantan Malaysia. Conference: The $2^{\text {nd }}$ International Conference on Applied Science and Technology. AIP Conference Proceedings 1891(1): 020143.

37. Shaw J, Ahmed I (2010) Design and delivery of post-disaster housing resettlement programs. Monash Asia institute Monash university, report 6 .

38. National disaster management guidelines (2010) Role of NGOs in Disaster Management. New Delhi, India.

39. Garson GD (2013) Testing statistical assumptions.

40. Field A (2009) Discovering Statistics Using SPSS. ( $3^{\text {rd }}$ edn), SAGE Publications Ltd, California, US

41. Sambasivan M, Soon YW (2007) Causes and effects of delays in Malaysian construction industry. International Journal of Project management25 (5): 517-526.

42. Enshassi A, Faisal MA, Tayeh BA (2010) Subcontractor prequalification practices in Palestine. The International Journal of Construction Management 10: 45-75.

43. Enshassi A, Arain F, Tayeh BA (2012) Major causes of problems between contractors and subcontractors in the Gaza Strip. Journal of Financial Management of Property and Construction17(1): 92-112.

44. El-Hallaq KH, Tayeh BA (2015) Strategic planning in construction companies in Gaza Strip. Journal of Engineering Research and Technology 2(2): 167-174.

45. Albhaisi MA, Tayeh BA, El-Hallaq Kh (2016) Variation orders in construction projects in Gaza Strip (Case Study: Qatar Projects). International Journal of Engineering and Management Research6(5): 262-270.

46. Tayeh BA, Al-Hallaq K, Sabha FA (2016) Effects of faulty design phase on school buildings maintenance in Gaza Strip. American Journal of Civil Engineering and Architecture 4(6): 199-210

47. Tayeh BA, Al-Hallaq K, Yusuf MO, Sabha FA (2017) Effects of construction phase errors on maintenance of school buildings in Gaza Strip. International Journal of Management, Information Technology and Engineering BEST: IJMITE 5(01): 21-34

48. Tayeh OA, El-Hallaq K, Tayeh BA (2018) Importance of organizational culture for Gaza Strip construction companies. International Journal of Engineering and Management Research IJEMR 8(1): 35-39.

49. Tayeh BA, Al-Hallaq K, Alaloul WS, Kuhail AR (2018b) Factors affecting the success of construction projects in Gaza Strip. The Open Civil Engineering Journal 12: 301-315.

50. Fengler W, Ihsan A, Kaiser K (2008) Managing post-disaster reconstruction finance.

51. Auffret P, Almoamer W, Camacho I, DCruz R, Rajab M, et al. (2009) Damage assessment and needs identification in the Gaza Strip. Report, Gaza Strip, Palestine.

52. Ruddock L, Amaratunga D, Palliyaguru R (2010) Post-tsunami reconstruction in sri lanka: assessing the economic impact. Strategic Property Management Journal 14(3): 217-230. 


\section{Civil Engineering Research Journal} (C) This work is licensed under Creative

DOI: $10.19080 / C E R J .2019 .08 .555740$
Your next submission with Juniper Publishers will reach you the below assets

- Quality Editorial service

- Swift Peer Review

- Reprints availability

- E-prints Service

- Manuscript Podcast for convenient understanding

- Global attainment for your research

- Manuscript accessibility in different formats ( Pdf, E-pub, Full Text, Audio)

- Unceasing customer service

Track the below URL for one-step submission https://juniperpublishers.com/online-submission.php 